\title{
DISCUSSION AND REFLECTION ON SEVERAL CORE ISSUES IN T GRAND CANAL HERITAGE CONSERVATION PIANNING UNDER THE BACKGROUND OF APPLICATION FOR WORLD HERITAGE
}

\author{
Yao Di ${ }^{a}$, Dai Desheng ${ }^{\mathrm{b}}$, Tang Yezheng ${ }^{\mathrm{c}}$, Zhu Guangya ${ }^{\mathrm{b}}$, Chen Xie $^{\mathrm{a}}$ \\ a Jiangsu Institute of Urban Planning and Design, Jiangsu Construction Building 903, Caochangmen Avenue 88, Nanjing, Jiangsu, \\ China -wkjxingxing@163.com \\ ${ }^{\mathrm{b}}$ School of Architecture, Southeast University, Nanjing, China - ddsanddd@ hotmail.com \\ ${ }^{c}$ Nanjing Academy of Urban Planning \& Design Co.,LTD, Xinhua Building 16F, Zhongshan Road 55, Nanjing, Jiangsu, China -
} 1934555@qq.com

Commission E, WG E/3

KEY WORDS: China's Grand Canal Heritage, Conservation Plan, Value Assessment, Protection Zoning

\begin{abstract}
:
At the turn of the century, a series of new heritage concepts have appeared in the area of international cultural heritage protection, such as cultural landscape, cultural route, heritage corridor, heritage canal, which presents the development of people's recognition of cultural heritage. According to The Operational Guidelines for the Implementation of the World Heritage Convention, management planning must be contained in the material used to apply for world heritage. The State Administration of Cultural Heritage designed the mission and work schedule of China's Grand Canal conservation planning in 2008. This research will introduce the working system of China's Grand Canal conservation planning on three levels: city, province and nation. It will also summarize the characteristics of the core technologies in China's Grand Canal conservation planning, including key issues like the identification of the core characteristic of China's Grand Canal, value assessment and determination of the protection scope. Through reviewing, thinking and analyzing the previous accomplishments, the research will offer some advices for the similar world heritage conservation planning after.
\end{abstract}

At the turn of the century, a series of new heritage concepts have appeared in the area of international cultural heritage protection, such as cultural landscape, cultural route, heritage corridor, heritage canal, which presents the development of people's recognition of cultural heritage. Under this historical background, the State Council declared the Beijing-Hangzhou Grand Canal (from the Spring and Autumn Period to Qing Dynasty) as the sixth key national cultural relics in 2006 and decided to apply for world cultural heritage in 2014. In March, 2008, the State Administration of Cultural Heritage held The Conference Concerning China's Grand Canal Applying for World Heritage and China's Grand Canal Conservation Planning Formulation Seminar in Yangzhou, which determined the tasks of China's Grand Canal conservation planning and the general schedule. Making such a big-scale conservation planning in the name of the country is unprecedented. The Chinese Academy of Cultural Heritage and Southeast University co-formulate The Requirements of Grand Canal Heritage Conservation Planning Formulation-Stage One (referred as Requirements in Stage One hereinafter) and The Requirements of Grand Canal Heritage Conservation Planning Formulation-Stage Two (referred as Requirements in Stage Two hereinafter) to guide the conservation planning formulation in cities and provinces respectively. This paper will focus on China's Grand Canal heritage conservation planning and analyze the main technological points during the planning process.

\section{CONSERVATION PLANNING SYSTEM AND BASIC STRUCTURE}

\subsection{Planning System}

China's Grand Canal runs through eight administrative provinces and municipalities and over thirty five prefeprocture cities. Conservation planning system consists of planning on three levels: The first level is the municipal Grand Canal heritage conservation planning, the second level is the provincial Grand Canal heritage conservation planning and the third level is the national general planning for China's Grand Canal heritage conservation and management.

The Chinese Academy of Cultural Heritage and Southeast University made Requirements in Stage One from June to December together in 2008. During the period from January to September in 2009, 35 cities (including municipalities) along China's Grand Canal made the municipal conservation planning. Requirements in Stage Two was made during the period from January to June in 2009. In August, 2009, formation of the provincial Grand Canal heritage conservation planning started. Formation of The General Planning for China's Grand Canal Heritage Conservation and Management started in March, 2010, and the first draft was submitted to relevant departments of the State Council for opinions in December, 2010. The General Planning for China's Grand Canal Heritage Conservation and Management was announced and implemented by China's Grand Canal conservation and inter-provincial consultant team that in charge of applying for world heritage (Zhu Guangya, 2012a) (Figure1). 


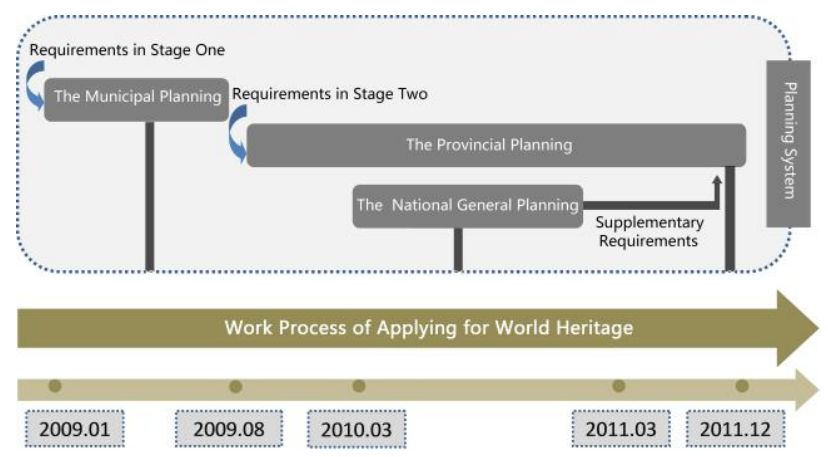

Figure 1. Planning system

\subsection{Planning Structure}

The structure of China's Grand Canal heritage conservation planning is in accordance with conservation planning by Chinese cultural relic protection units. According to Requirements in Stage One, the outline includes: 1. General rules. 2. The identification of China's Grand Canal heritage. 3. Assessment. 4. Protection zoning. 5. Requirements of display planning. 6. Requirements of conservation and management. 7. Requirements of archaeological planning. 8. Planning stages. 9. Suggestions for relevant planning. 10. Maps and drawings. Requirements in Stage Two has no difference in layout and main contents except the addition of heritage grading requirements. From the real situation in planning-making, the focus of every stages in China's Grand Canal heritage conservation planning is the identification of China's Grand Canal heritage, value assessment and protection zoning.

\section{THE IDENTIFICATION OF CHINA'S GRAND CANAL UNDER THE BACKGROUND OF APPLICATION FOR WORLD HERITAGE}

\subsection{Core Features of China's Grand Canal}

There are many different opinions of how to understand the features and connotation of China's Grand Canal heritage in the field of heritage conservation since China's Grand Canal heritage drew attention gradually. Among them, there are some representatives: scholars led by Ruan Yisan advocated to understand and assess China's Grand Canal heritage in the concept of cultural route (Ruan Yisan et al, 2008a). Scholars like Yu Kongjian believed that the concept of heritage corridor should be introduced into China's Grand Canal conservation planning and application for world heritage (Liwei et al, 2004a). While Xu Songling claimed China's Grand Canal should be regarded as "serial heritage"(Xu Songling, 2010).

The core feature of China's Grand Canal heritage determines what type of world heritage to apply for, and it also affects the classification and selection of the resources in the conservation planning and the direction of value assessment. If it is regarded as a cultural route, China's Grand Canal heritage should be classified and graded according to its historic significance and cultural implication. Starting from the angle of water conservancy project, watercourses and hydraulic facilities will be main factors of China's Grand Canal heritage. As planning carries on, the planning team realizes that their understanding of China's Grand Canal heritage in the past is focused on its historic and humanistic value, and researches about engineering technologies employed in China's Grand Canal are rare. The
World Canal Heritage List points out that the importance and value of a canal heritage can be measured in the following aspects: technological factor, economic factor, social factor and landscape, among which the technological factor is the core. The feature of engineering technologies in China's Grand Canal has gradually become the focus of the planning (Figure2).
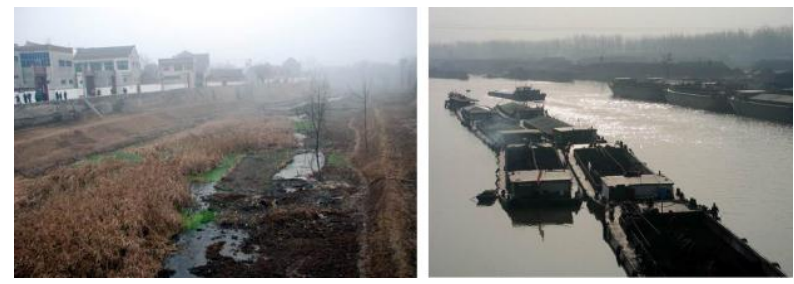

Innavigable Hebi section Navigable Jining section
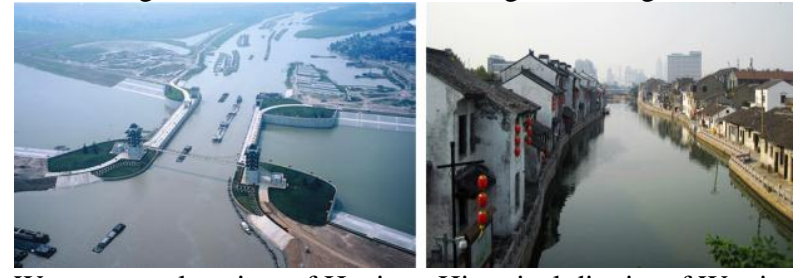

Water control project of Huaian Historical district of Wuxi

Figure 2. Status of different canal sections

\subsection{The Identification of China's Grand Canal Heritage}

China's Grand Canal heritage includes related rivers and all kinds of relics and remains directly involving in the development of China's Grand Canal. The relics and remains have outstanding universal value, and they can represent the history and importance of China's Grand Canal water conservancy project and can be proved by relevant archaeological evidence, substance, scientific data and definite documentary. Considering legal protection types of Chinese cultural heritage, the priority of requirements in both stages is the principle of recording all kinds of relevant heritages and their setting. Requirements in Stage One classifies China's Grand Canal heritage into five categories, China's Grand Canal water conservancy project and relevant cultural heritage, China's Grand Canal settlement heritage, other tangible cultural heritage of China's Grand Canal, China's Grand Canal environment and landscape and other relevant intangible cultural heritage of China's Grand Canal.

Considering that engineering technology value is the core value of China's Grand Canal heritage, Requirements in Stage Two lists "water conservancy and water transportation project heritage" as the first core Canal heritage. The General Planning for China's Grand Canal Heritage Conservation and Management in stage three divides the resources of China's Grand Canal heritage into Canal hydraulic heritage, Canal affiliated heritage and Canal relevant heritage based on the closeness to features of engineering technologies of China's Grand Canal.

\section{VALUE ASSESSMENT OF CHINA'S GRAND CANAL UNDER THE BACKGROUND OF APPLICATION FOR WORLD HERITAGE}

\subsection{Value Types of China's Grand Canal}

Application for the world heritage stimulates people to think about the multi-values of China's Grand Canal heritage. From the accomplishments of municipal conservation planning in 
stage one, we can see that there are two orientations in municipal planning: value system in traditional cultural relics conservation planning and value assessment carried under the standard combining with world heritage. For example, some provinces (Hebei and Anhui) assess China's Grand Canal heritage based on three aspects: history, science and art; some cities (for instance: Changzhou city, Jiangsu province) assess China's Grand Canal heritage in contrast to several world cultural heritage standards; and some other cities (all cities in Zhejiang province) assess China's Grand Canal heritage in combination with historic, scientific and artistic value based on the concept of heritage canal and cultural route. In terms of value types, it involves historic value, scientific value, cultural value, social value, tourism value and landscape value, etc. The value types finalized during the conservation planning in stage three according to four factors in The World Canal Heritage List: technology, economy, society and landscape.

\subsection{Value Assessment of China's Grand Canal heritage}

Combination of integral assessment and classified assessment and combination of qualitative assessment and quantitative assessment are two important methods. In the Stage three of planning, the planning team pays more attention to system value based on the features of engineering technologies in China's Grand Canal heritage, thus they adopted the method combing all-line assessment with section assessment.

3.2.1 Combination of Integral Assessment and Classified Assessment: In municipal conservation planning, most cities carried out integral assessment and classified assessment. Integral assessment means elaboration on the type of value of China's Grand Canal heritage, for instance an integral textual elaboration on some part of the Canal in historic value, scientific value and artistic value. Classified assessment means different assessment methods in correspondence to different types of heritage. Some employ qualitative elaboration, and some formulate quantitative assessment indicator system. Different types of heritage possess different features, and the practical situations of China's Grand Canal heritage in different parts are different, therefore, 35 cities do not employ a unified assessment method.

3.2.2 Combination of Qualitative Assessment and Quantitative Assessment: Some cities (for instance: Beijing, Changzhou and Zhenjiang in Jiangsu province) employed the technology of GIS to do qualitative assessment and quantitative assessment in their conservation planning. Quantitative assessment needs an assessment indicator system to grade individual heritage to determine its value. Quantitative assessment gives a more specific grade of the value of heritages and makes a contrast between them in order to decide the key conservation requirements. However, some factors in this assessment, like historic value, engineering technology, planning technology and affection, authenticity and integrity of the project, can only be estimated combining with documentaries and interviews. Qualitative assessment can make up for the shortcoming of quantitative assessment.

\section{PROTECTION ZONING OF CHINA'S GRAND CANAL HERITAGE}

\subsection{Protection Zoning in the Third Level Conservation Planning}

Protection zoning is the key content in conservation and management of China's Grand Canal heritage. China's Grand Canal heritage conservation planning can be divided into three stages. It needs to be specific in the conservation planning about the relationship of the protection zoning in these three stage conservation planning and the standard to follow when there are differences.

Considering the reality situation that the municipal level planning was finished before Provincial and national level planning, the General Planning of the Grand Canal Heritage Conservation and Management stipulate that setting the principle of the Grand Canal heritage protection area and development controlling area should base on adjusting and integrating the protection zone which set by the Stage one planning. However, specific boundary of protection zone and development area in provincial level planning could consider the specific condition of difference province, and it still is guidance and principle-based boundary (CACG, 2011). At last, all cities should carry out assessment of protection zoning and protection demands of the Grand Canal heritage under the guideline of provincial planning. If there are no severe conflicts, it should be carried out in accordance with municipal level planning. Therefore, the main purpose of the protection zoning in provincial level planning and national level planning is uniform standard, and the feasible protection zoning lies in municipal planning.

\subsection{Protection Zoning in Municipal Conservation Planning}

There are two outstanding characteristics of Protection zoning in municipal conservation planning:

The first one is emphasis on the principle of legality. The municipal conservation planning should allow different competent departments to manage and protect China's Grand Canal heritage according to their own laws and regulations and relevant planning, because of the complexity of China's Grand Canal heritage and involvement of different kinds of regulations and rules of different management departments. For example, protection of settlement heritage like historical cultural cities, historical towns and well-known villages should follow cultural heritage protection laws and relevant laws and regulations in urban and rural design.

The second one is the concept of China's Grand Canal heritage protection belt. Several types of concepts in protection zoning can explain the wide range of industries involved. For example, the protection zoning of cultural heritage protection sites is scope of protection and establishment of control area, but the watercourses in hydraulic heritage has the concept of management under water conservancy department. Requirements in Stage One tries to accommodate the previous types with the concept of China's Grand Canal Protection belt, allowing all kinds of protection zoning in China's Grand Canal heritage overlapping. 


\section{REFLECTION ON THE PLANNING}

The first draft of The General Planning for China's Grand Canal Heritage Conservation and Management submitted to relevant department of the State Council for opinions in December, 2010. After two years of modification, it was finally declared and implemented in December, 2012. Improvement opinions from relevant departments represent different values and interest demands. Although the planning team discussed the problem that core technologies should approach international standard and be in accordance with our national conditions at the same time during the process of planning, the operability of the protection zoning still faces a lot of queries due to the implicit cohesive mechanism between relevant departments. Conservation planning of linear, large-scale and cross-system cultural heritages like China's Grand Canal is still in exploring, and making adjustment in compiling techniques and methods will still be the theme in a long run.

\section{REFERENCES}

CACG, 2011. The General Planning for the Grand Canal Heritage Conservation and Management (2011-2030).

Liwei et al, 2004a. Theoretical Framework for Integral Protection of Heritage Corridor and the Grand Canal. Urban Problems, 2004(1), pp. 28-31

Ruan Yisan et al, 2008a.Value Assessment, Cultural Route and the Grand Canal Protection. China Ancient City, 2008(1), pp. $38-43$

Xu Songling, 2010. http://www.china001.com/show_hdr.php?

xname $=$ http://www.china001.com/show_hdr.php?xname=PPD DMV0\&dname $=I 12 C C 51 \& x p o s=16$ (8 Oct. 2011)

Zhu Guangya, 2012a. Cultural Accumulation of the Grand Canal and Its Fate in the New Century. Southeast Culture, 2012(1), pp. 6-17 